\title{
Research
}

\section{Tweak, Adapt, or Transform: Policy Scenarios in Response to Emerging Bioenergy Markets in the U.S. Corn Belt}

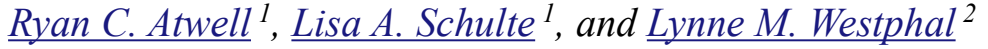

\begin{abstract}
Emerging bioenergy markets portend both boon and bane for regions of intensive agricultural production worldwide. To understand and guide the effects of bioenergy markets on agricultural landscapes, communities, and economies, we engaged leaders in the Corn Belt state of Iowa in a participatory workshop and follow-up interviews to develop future policy scenarios. Analysis of workshop and interview data, in conjunction with the results of regional social and ecological research, was used to develop a heuristic model outlining interactions between key drivers and outcomes of regional landscape change. Three policy scenarios were built on this framework and included the following approaches: tweak, adapt, and transform. Our results suggest that if macroscale markets, technologies, and federal farm policies are allowed to be the overriding drivers of farm owner and operator decision making, Iowa's agricultural landscapes will likely become highly efficient at row crop production at the cost of other desired outcomes. However, the perspectives of Iowa leaders demonstrate how multifunctional agricultural landscapes can be achieved through a concerted portfolio of change coordinated across local, regional, and national scales.
\end{abstract}

Key Words: agriculture; complexity; ecosystem services; Iowa; participatory; perennials; resilience; scale; social-ecological systems

\section{INTRODUCTION}

Bioenergy crops have been heralded as an environmentally beneficial alternative to global consumption of fossil fuel (Ragauskas et al. 2006). However, mounting research shows that the devil may be in the details; long-term sustainability of bioenergy production will be determined by interactions among ecological, social, and economic factors that are unique to particular bioregions, cultures, and economies (Jordan et al. 2007, Field et al. 2008, Robertson et al. 2008, Porter et al. 2009). Evaluating the efficacy of regional approaches to bioenergy production is, therefore, integral to realizing the potential societal benefits of this emerging industry.

The U.S. Corn Belt is one well-studied agroecosystem that illustrates the complex potential impact of bioenergy markets on natural resources, and Corn Belt stakeholders have expressed concern about how the rapid development of these markets will impact regional social, economic, and environmental sustainability (Hinkamp et al. 2007).
For instance, rising demand for corn-based ethanol is currently leading to more land planted in annual monoculture crops and less in diverse perennial cover (Secchi et al. 2008). Loss of perennial vegetation is associated with declining biodiversity, water quality, flood control, and other ecosystem services (Schulte et al. 2006, Landis et al. 2008, Broussard and Turner 2009). In particular, the export of agricultural nutrients, i.e., nitrogen and phosphorous, associated with row crops to Corn Belt river systems is a key driver of downstream hypoxia in the Gulf of Mexico (US EPA 2007).

Emerging research indicates that small, carefully targeted networks of perennial cover within Corn Belt agricultural landscapes, e.g., constructed wetlands, stream buffers, pasture, diverse crop rotations, and certain biomass energy crops, could disproportionately benefit regionally impaired ecosystem function (Schulte et al. 2006, Jordan et al. 2007, Nassauer et al. 2007). Incorporating perennial crops for food and bioenergy at strategic locations in agricultural landscapes may also be an effective strategy in addressing a global need for 
balanced production of food, fiber, energy, and ecosystem services (Porter et al. 2009, Vitousek et al. 2009, Glover et al. 2010).

Corn Belt farm owners and operators are, however, hesitant to alter farming practices and voice little efficacy to influence the technologies, institutions, and policies that drive regional land use (Atwell et al. 2009a). Both rural stakeholders (Atwell et al. 2009b) and regional leaders (Atwell et al. 2010) indicate that successful implementation of perennial conservation initiatives is dependent upon policy mechanisms that address complex, multiscale interactions among ecological and social drivers in the system.

To facilitate the development of such policy mechanisms, we conducted a participatory workshop and follow-up interviews to integrate the insights of Corn Belt leaders with the results of regional social and ecological research, including companion studies investigating how rural stakeholders perceive agricultural landscapes and perennial conservation practices (Atwell et al. $2009 a, b, 2010)$. Our objectives were to (1) understand how regional leaders viewed ecological and social drivers of Corn Belt land use change, and (2) to develop alternative policy scenarios that could bolster resilience of desirable system configurations. In particular, we probed how perennial conservation practices could be implemented to promote ecosystem services and other societal goods in the midst of emerging bioenergy production markets. Here we present resulting policy scenarios using the framework provided by resilience science.

Resilience science is an emerging approach to address complexity and change in linked socialecological systems (Gunderson and Holling 2002, Folke 2005). "Resilience" is a loosely defined concept that refers to the amount of change that a system can undergo and still maintain its essential configuration; resilience can also refer more generally to a system's capacity for selforganization, learning, and adaptation (Brand and Jax 2007). The goal of resilience analysis is to understand and bolster the resilience of desirable system configurations while avoiding those that are undesirable (Walker et al. 2002). This includes analyzing how social actors "adapt" to maintain systems in their present state or "transform" systems into alternative states. Resilience science emphasizes the inclusion of multiple stakeholder groups in scientific and decision making processes to understand a system from different viewpoints. Scenario planning is a strategy often used within resilience science to formally consider uncertainty (Peterson et al. 2003, 2004). Alternative scenarios that describe a range of future system trajectories are designed to be consistent with what is known about causal processes; they also highlight how key decision points might influence system behavior under a range of assumptions and conditions developed through stakeholder input.

\section{METHODS}

Although our research objectives address the biophysical scale of the U.S. Corn Belt agroecoregion, we focused the policy workshop and resulting analyses on the state of Iowa (Fig. 1). The Corn Belt is a region of temperate climate and deep soils that spans 13 states in the north central U.S. The region was formerly comprised largely of tallgrass prairie and is now dominated by intensive agricultural production. Iowa lies in the center of the U.S. Corn Belt and is the only state that lies entirely within this agroecoregion. Many organizations and policy decisions that affect agricultural land use change are made at the state level, and state level actors and decisions in turn influence, and are influenced by, national agricultural policy.

The participatory policy workshop, and the resulting models and scenarios, presented in this paper are the capstone of a larger interdisciplinary study (Fig. 2). As we explain below, workshop participants were asked to consider and build upon previous research, including a companion study integrating the perspectives of farmers and other rural Iowa stakeholders. We also explain how the models and scenarios presented in this paper were developed through the participatory policy workshop, but with consideration of other aspects of our larger research project.

Strategic sampling (Handwerker 2005) and assistance from agency and nonprofit partners were used to select key leaders in agriculture, conservation, and policy in Iowa as workshop participants (Atwell et al. 2010). Participants held positions of influence in organizations that encompass the multiplicity of perspectives that drive state-level land use decisions (Table 1). Sixteen of the 17 leaders whom we invited agreed to participate. Two were unable to attend because 
Fig. 1. The state of Iowa and the Corn Belt agroecoregion within North America.

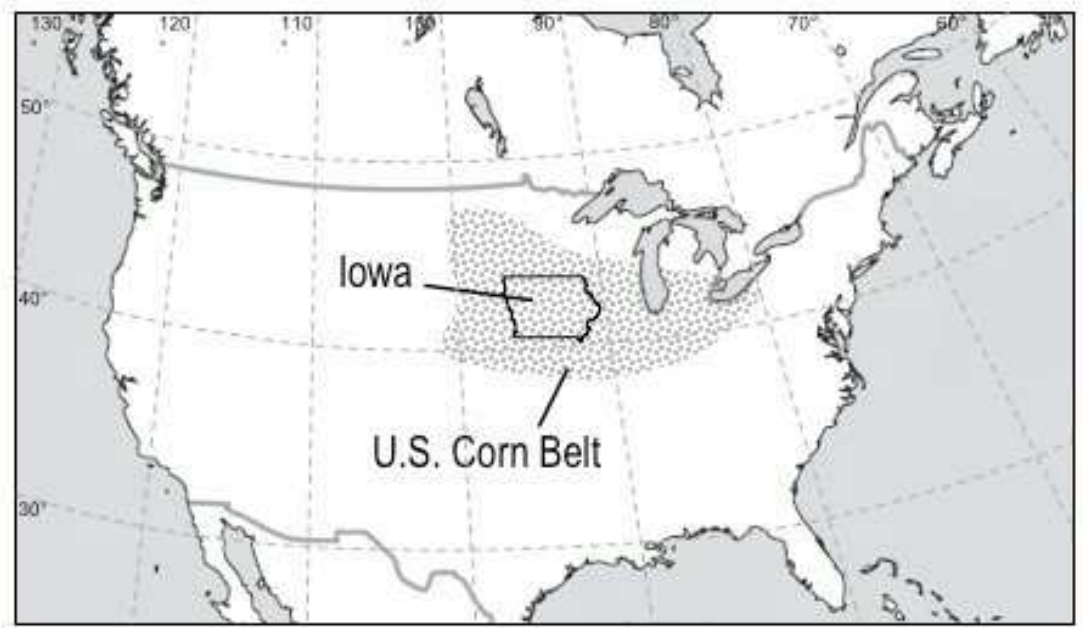

of an extended legislative meeting. The remaining 14 invitees participated in the workshop.

Upon arrival, participants filled out a questionnaire that probed individual perspectives on agricultural land use change. To provide a common starting point, the workshop began with a brief presentation outlining our research objectives and highlighting the results of companion studies exploring stakeholders' perspectives on land use and perennial conservation strategies (Atwell et al. 2009a,b). This included a brief presentation of a preliminary version of a heuristic model outlining the social and ecological drivers of land use change in Iowa agricultural landscapes. We then facilitated a 2.5 hour dialogue on current and future land use practices, institutions, and policies in Iowa.

The discussion was recorded using audio and visual media, but anonymity of participants' comments in research reports was guaranteed to foster a candid dialogue. The lead author coded the workshop transcript into thematic categories using a qualitative approach (Miles and Huberman 1994) and NVivo7 data management software (QSR 2006). Themes were identified by comparing similarities and dissimilarities (including agreement or disagreement) in the data by sorting and assigning coded data into different hierarchical groupings, and by looking at the use of emphasized or recurring phrases, metaphors, and stories (Atwell et al. 2010).
We integrated these workshop themes with the results of rural stakeholder interviews and other social and ecological research (Fig. 2) to further develop a heuristic model illustrating how desired multiobjective regional outcomes hinge upon the interactions among key social and ecological variables (Fig. 3, Table 2). This model provided the underlying causal framework upon which future policy scenarios were built (Fig. 2; Walker et al. 2002, Peterson et al. 2003). Although these scenarios were written by our research team, all of their narrative content was gathered from themes that arose directly from qualitative analysis of the policy workshop and rural stakeholder interviews. This included consideration of negative, or conflicting, evidence in our data that challenged or added caveats to primary themes. As part of the qualitative analysis process, scenarios were further shaped by comparing and contrasting workshop and interview data and themes with resilience theory.

Results of preliminary analyses, including workshop themes and written scenarios, were presented to all workshop participants and their feedback was recorded in individual interviews. This interview data was incorporated into further analyses and refinement of themes and scenarios. As part of the ongoing process of qualitative analysis, the content of and the relationships between workshop and interview data, the heuristic model, and future scenarios were subjected to 
Fig. 2. The heuristic model and scenarios presented in this paper were built upon data from several stages of a larger research project.

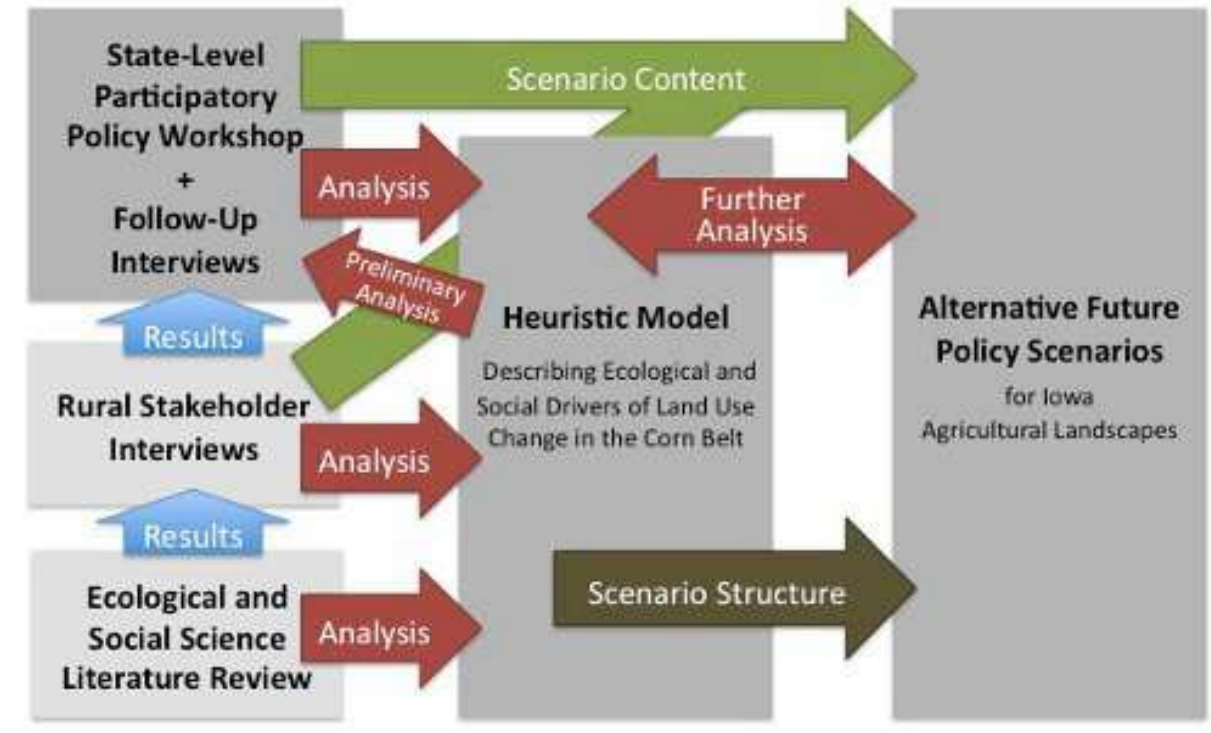

iterative rounds of criticism, scrutiny, and development by our research team.

\section{RESULTS}

Leaders in Iowa agriculture, conservation, and policy arenas helped to explicate, corroborate, and add caveats to scientific understanding of the relationships among bioenergy markets, agricultural land use, and desired societal and ecosystem outcomes (Fig. 3, Table 2). Individual workshop participants placed emphasis on different components of this model, and sometimes did not recognize certain aspects of it. However, three different interpretations of this model emerged through workshop dialogue, data analysis, and follow-up interviews as capturing collective approaches that, taken together, could be agreed upon by the group as a whole to represent alternative visions of the future (Figs. 4a-4c). These models were developed into the following policy scenarios: (1) tweak, (2) adapt, and (3) transform.

\section{Scenario 1: tweak}

The ethanol boom leads to a $10 \%$ increase in land planted in corn, and changing markets and emerging technologies become the primary drivers of land use. With world demand for food and energy increasing, Iowans take pride in the high production capacity of their farms, and industrial agriculture dominates the landscape. Public sentiment holds that ecological sacrifices must be made across Iowa's rural areas to meet the demand for agricultural products. Legislation to monitor and regulate agriculture's impact on natural resources is met with resistance, except in a few watersheds characterized by high exurban development or by lakes and rivers of regional importance.

Climate change leads to an increase in the severity of storms, and regional conservation efforts focus on water quality and flood control. Biodiversity is perceived to be too complex and too expensive to be of practical concern within working agricultural landscapes. Federal farm programs are used to promote the implementation of perennial cover and 
Table 1. Workshop participants represented the following organizations.

Agricultural nonprofit groups

Commodity Director, Iowa Farm Bureau

Director of Environmental Affairs, Iowa Farm Bureau

Director of Environmental Programs, Iowa Soybean Association

Crop Consultant and Program Specialist, Practical Farmers of Iowa

Business

Accredited Farm Manager and Agricultural Consultant, Hertz Farm Management

Conservation nonprofit groups

Director, Iowa Natural Heritage Foundation

Public Policy Consultant, Iowa Natural Heritage Foundation

Agricultural Watershed Director, Upper Mississippi River Basin Initiative, The Nature

Conservancy

Government

Director, Iowa Department of Natural Resources

Iowa Secretary of Agriculture, Iowa Department of Agriculture and Land Stewardship

Director, Iowa Office of Energy Independence

Assistant State Conservationist for Water Resources, Natural Resource Conservation

Service, U.S. Department of Agriculture

Former Director, Hamilton County Conservation Board

Agricultural Advisor, Iowa office of U.S. Senator Tom Harkin

other conservation practices at key landscape positions. Some farmers choose to participate in these programs, but most do not. In watersheds of unique interest, initiatives are funded by special interest groups and government agencies to improve ecosystem services, but these efforts are seldom coordinated and often compete for limited resources.

As crop prices outpace conservation subsidies, there is a trend toward loss of land in conservation set- asides and more hectares are devoted to row crop production. Because of loss of perennial vegetation and inconsistent adoption of conservation practices, levels of pollutants in regional rivers remain high during periods of high precipitation. Loss of native grassland species continues, and the downstream Gulf of Mexico hypoxic zone continues to grow. Government commodity subsidies become increasingly unpopular with urban voters, and the amount of federal assistance flowing into rural areas decreases. As aging farmers retire, the amount of land in large 
Fig. 3. Analysis of workshop data and the results of other regional studies highlighted key drivers and focal relationships influencing land use in Iowa's agricultural landscapes (Table 2). Exogenous system drivers are macroscale influences on the system that set the range of possible futures. Endogenous drivers are regionally controlled system components that vary across potential futures to influence the patterns and processes of future landscapes. Exogenous and endogenous drivers combine to influence multiple ecosystem services and societal goods, all of which were seen as important outcomes of rural landscapes.

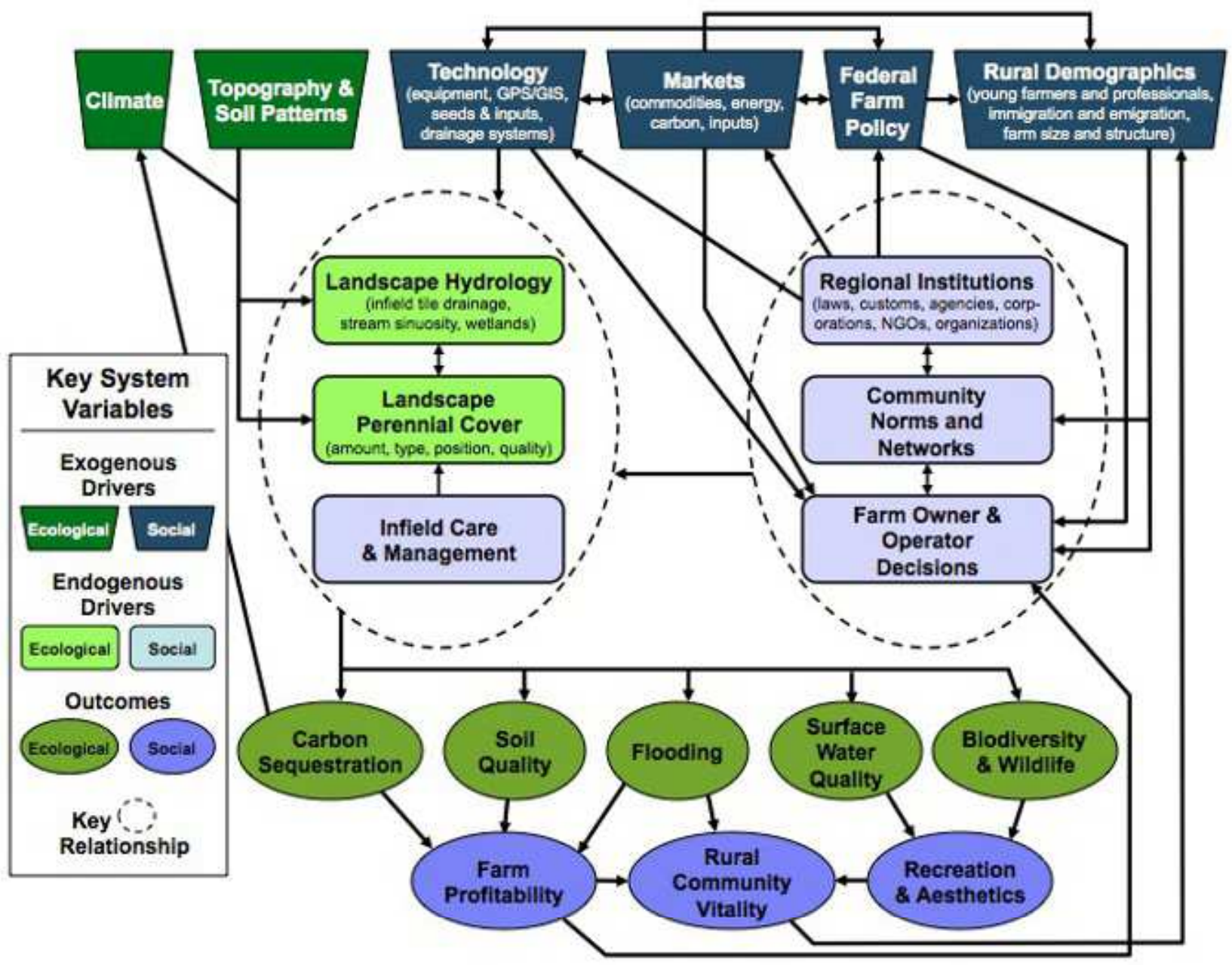

farms owned by outside investors grows and more farms are operated by hired laborers. Rural populations of middle class farmers and young professionals continue to decline as people move to regional hubs.

\section{Scenario 2: adapt}

Iowans increasingly demand multifunctional agricultural landscapes that provide crops, livestock, water quality, flood control, recreation, scenic value, and wildlife habitat. Corn-based ethanol production leads to increased row crop production, rising crop prices, and increased 
Table 2. The relationships among different drivers and outcomes (Fig. 1) of land use in the Corn Belt social-ecological system.

\begin{tabular}{|c|c|}
\hline Interaction & Description \\
\hline $\begin{array}{l}\text { Climate, Topography, and Soils } \\
\text { Land Cover and Hydrology }\end{array}$ & $\begin{array}{l}\text { Basic ecological relationships facilitate and constrain } \\
\text { interactions among other aspects of the system. The Corn } \\
\text { Belt has a temperate climate and deep glacial soils, making } \\
\text { it one of the most versatile agricultural regions in the world. } \\
\text { Based on soil and topographical patterns, different } \\
\text { landscape positions are better suited to different agricultural } \\
\text { and conservation uses. Future global climate change may } \\
\text { impact average temperature and precipitation, weather } \\
\text { severity, and the regional fit of different cover types in ways } \\
\text { that are difficult to predict. }\end{array}$ \\
\hline Policy $\longleftrightarrow$ Markets & $\begin{array}{l}\text { U.S. federal farm policy is designed, in part, to impact the } \\
\text { markets of different kinds of crops. In recent decades, a high } \\
\text { proportion of federal support for farms has been directed to } \\
\text { create price supports for production of commodity row } \\
\text { crops such as corn and soybeans. Federal regulations and } \\
\text { subsidies can also be instrumental in helping to spur new } \\
\text { technologies and markets, e.g., corn-based ethanol. }\end{array}$ \\
\hline $\begin{array}{c}\text { Technology } \\
\text { Hydrology, Land Cover, Infield Care }\end{array}$ & $\begin{array}{l}\text { Agricultural and environmental technologies influence what } \\
\text { is possible in land use and care. Currently, emerging } \\
\text { technological pathways associated with different types of } \\
\text { bioenergy production are influencing new patterns in land } \\
\text { cover and care, which in turn enhance or erode ecological } \\
\text { outcomes. The region's hydrologic structures are } \\
\text { collectively managed entities that have been altered over } \\
\text { decadal time frames through changes in technology, policy, } \\
\text { institutions, and cultural norms. }\end{array}$ \\
\hline Markets and Policy & $\begin{array}{l}\text { Over the last several decades, declining crop prices and } \\
\text { increasing input costs have lowered farmers' terms of trade } \\
\text { leading to the need for operators to farm more land to make } \\
\text { a living. Although agricultural policies have provided } \\
\text { funding to support the agricultural system, most of this } \\
\text { money supports large-scale commodity crop farms, e.g., } \\
\text { corn and soybeans, and land owners, who may not live in } \\
\text { rural areas. This has led to fewer farmers in rural areas, an } \\
\text { increase in average farmer age, and a decrease in } \\
\text { population, numbers of young farmers, commerce, and } \\
\text { connectedness in rural communities. }\end{array}$ \\
\hline
\end{tabular}

Technology, Markets, and Farm Profitability<smiles>C=[V]</smiles>

Farmer Decisions
Changing markets and emerging technologies influence farmers' land use decisions. To make a living, farmers must be attentive to the profitability of their farms. If new agricultural and conservation practices are to be adopted at broad scales, they must be profitable and fit with current technological and market trends in agriculture.

\section{References}

Alley et al. 2003, Schulte et al. 2006, Millar et al. 2007

Workshop Data; Keeney and Kemp 2002 create price supports for production of commodity row crops such as corn and soybeans. Federal regulations and subsidies can also be instrumental in helping to spur
technologies and markets, e.g., corn-based ethanol.

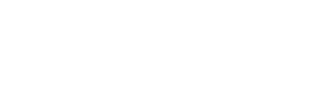

Workshop Data; Landis et al. 2008, Atwell et al. 2009b, Porter et al. 2009

Heady et al. 1965, Keeney and Kemp 2002, EWG 2006, Lobao and Stofferahn 2007

McCown 2005, Atwell et

al. $2009 a, b$ 
Federal Farm Policy

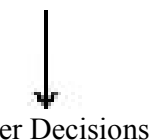

Farmer Decisions

Rural Demographics

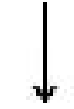

Community Norms and Network; Farmer Decisions

Regional Institutions

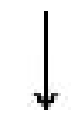

Agricultural Technology, Markets, and Federal Farm Policy

Regional Institutions

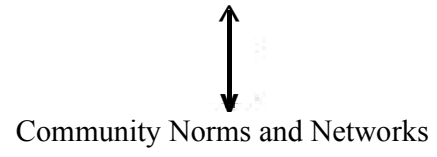

$\uparrow$

Farmer Decisions
Federal farm policy has been shown to influence farmer decisions in many ways. Commodity and conservation subsidies have had widespread impacts on land use at broad scales. The ways in which policies are funded and implemented at local levels can also play a key role in mediating enforcement of regulations and farmers' participation in incentive programs. Long-term, consistent, and straightforward programs that are compatible with farm practices, priorities, and profitability are more likely to elicit high participation.

Changing demographics, including loss of people, especially young farmers, from the land and decline in community commerce and vitality, impacts the quality and connectedness of life in rural communities. Because many farmers are nearing retirement and do not know who will farm their land after them, they are reticent to make major changes in their farming practices. Corn Belt stakeholders emphasized that potential for change in other aspects of the system hinges upon bolstering the vitality of the region's struggling rural communities.

Agricultural and conservation interests in the Corn Belt, including policy makers, government agencies, and large nonprofit and lobby groups, have an influence on federal farm policy. Our workshop participants indicate that these regional institutions have the potential to influence the development of new markets and technologies to empower agricultural land uses that can achieve desired outcomes.

Farmers' decisions are based upon many factors that operate at several different scales, and are not purely rational economic evaluations. The interaction among community social norms and networks and regional institutions, e.g., societal laws and customs, government agencies, nonprofit organizations, agricultural and conservation groups, can play a key role in mediating the influence of macroscale markets, technologies, and policies on farmers' land use values and decisions.
Workshop data; Keeney and Kemp 2002, McCown 2005, Atwell et al. 2009a, 
Institutions, Community Norms and

Networks, Farmer Decisions

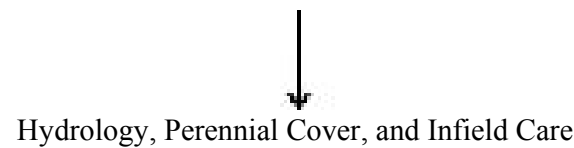

Hydrology, Perennial Cover, and Infield Care

Hydrology, Perennial Cover, Infield Care

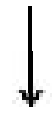

Carbon Sequestration, Soil and Water Quality, Flooding, Biodiversity

Perennial Vegetation
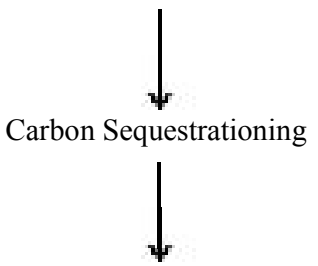

Climate Change

Water, Wildlife, and Biodiversity

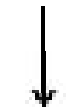

Rural Vitality
Because $90 \%$ of the land in the Corn Belt lies in privately owned and operated farms, the form and function of landscape-scale hydrological systems and vegetation patterns hinge upon the collective decisions and careful management of farm owners and operators. Social norms and the involvement of regional institutions such as

agriculture and conservation nonprofit organizations or government agencies, in community networks also interplay with farmer decisions to impact hydrology, land use, and land care at landscape scales.

Building soil quality, carbon sequestration, biodiversity, and controlling the loss of water and nutrients from the land, require attention to the interaction between hydrology, and the amount, type, position, and quality of perennial cover in agricultural landscapes. To achieve these outcomes, landscape-scale planning and careful management of both hydrologic structures and infield cropping systems is essential.

Forests, grasslands, and other forms of vegetative cover are instrumental in absorbing carbon from the atmosphere and offsetting the effects of greenhouse gas emission on global climate change. When compared to either corn-based ethanol or soy biodiesel, biofuels made from diverse perennial mixtures have been shown to sequester more carbon, produce greater energy per unit area, and lead to greater reductions in green house gas emissions.
Workshop Data; USDA

NASS 2004, Morton

2008, Atwell et al. 2009a

$b, 2010$
Workshop Data; Crumpton 2001, Schultz et al. 2004, Schulte et al 2006, Jordan et al. 2007 Nassauer et al. 2007, Hatfield et al. 2008, Landis et al. 2008,

Broussard and Turner 2009

Tilman et al. 2006, Millar et al. 2007
Both social and economic benefits have the potential to be realized through landscape change targeting biodiversity. Regional counties that include, or are surrounded by, natura amenities such as green belt trails, preserves, and lakes are increasing in per capita income. Rural residents in a large
Stein et al. 1999

Santelmann et al. 2004,

Monchuck et al. 2007
Recreation and Aesthetics

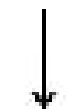 agricultural watershed in the Upper Midwest assign high value to living in a healthy environment, conserving natural resources for future generations, and experiencing a serene and peaceful natural environment.
$\downarrow$

pressure on the region's water and soil resources. As a result, federal subsidies that reward corn and soybean production become politically untenable. To transfer federal funding toward rural community and environmental development, farm groups and conservation groups join forces to create economic opportunities associated with delivery of ecosystem services. Iowa environmental agencies begin widespread monitoring of nutrients and other agricultural pollutants discharged from underground field drainage systems and small order streams.

Iowa becomes a national leader in addressing nonpoint source environmental dilemmas by implementing a water quality and flood control trading system whereby farmers with low pollution and high water retention can sell credits to entities with substandard environmental performance. The state leverages federal funding to offer competitive block grants to groups of farm owners and operators on a watershed basis to meet environmental standards in creative ways. Incentives are offered for the implementation of public access points, trail networks, and wildlife habitat. State and federal farm policy provides funding for trained conservation personnel to identify and work directly with individual farm owners and operators at the county level. 
Fig. 4. Three possible future scenarios for Iowa agroecosystems were developed from workshop themes: tweak (4a), adapt (4b), and transform (4c). Scenarios were all built upon the same heuristic model (Fig. 3 ), but differ in their prioritization of different systemic relationships (gray arrows represent normal relationships; darker arrows represent relationships that are prioritized in a given scenario). In "tweak" (4a), macroscale forces were seen as driving regional outcomes, but beyond regional control. This scenario also omits certain relationships that were seen as being impractical or of little importance by proponents of this scenario. In "adapt" (4b), policies, partnerships, and programs are based on understanding regional social-ecological complexity and are designed to achieve desired multiobjective outcomes. "Transform" (4c) recognizes regional social-ecological system complexity and focuses on directly influencing powerful top-down drivers to catalyze and equip new markets that have the power to reorient the regional system to a desired configuration.

a.

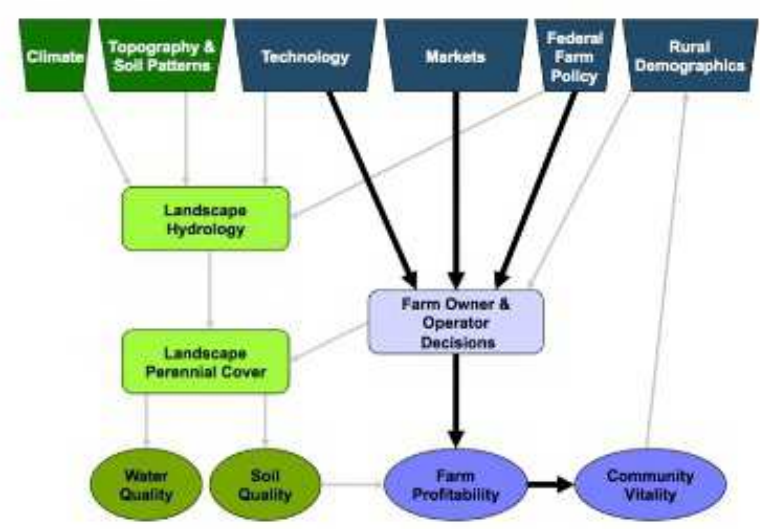

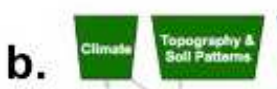
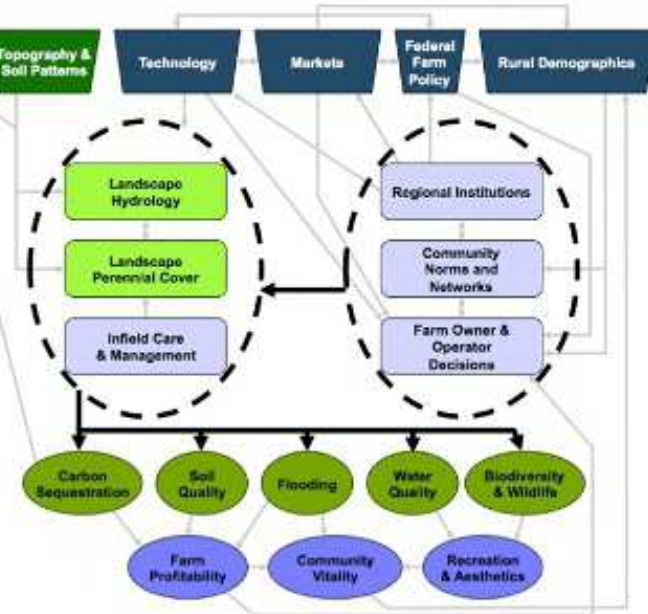

c.

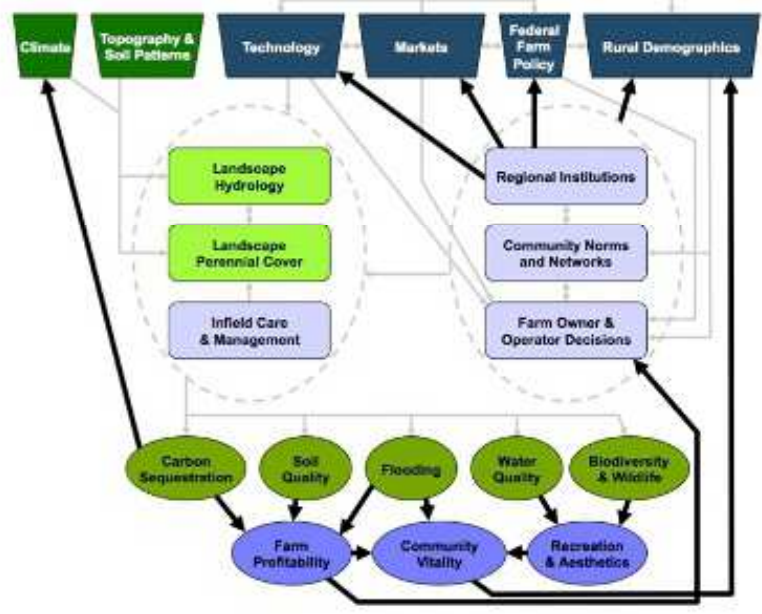


Because of more sources of cultural and institutional support for farm owners and operators who make choices to advance conservation on their farms, Iowa's countryside sees a marked increase in perennial cover. Off-season cover crops retain soil, uptake water, and replenish nutrients during rainy months. Networks of riparian buffers square field edges for large farm equipment and allow oncechannelized streams to meander, connecting reconstructed wetlands that purify, retain, and slow the movement of water. As a result of landscape scale changes in hydrology and vegetative cover, biodiversity and populations of desirable game species rebound and regional soil and water quality hold steady over decadal timeframes. However, limited government conservation funding and the slow response time of government programs cannot keep pace with the power of agricultural markets and technologies. Intensive row crop production continues to be the primary driver of land use in Iowa.

\section{Scenario 3: transform}

A group of regional leaders in agriculture, conservation, and policy are brought together by the questionable long-term sustainability of row crop agriculture and corn-based ethanol. They envision a future where the emerging bioeconomy will usher in a period of rapid system reorganization, presenting unique opportunities to reshape Iowa's agriculture, countryside, and commerce. These leaders and their constituencies set a goal: to double the real value of Iowa's agricultural economy over the course of 25 years. Their approach is to build appropriately scaled markets, production systems, and landscapes that balance use and conservation of Iowa's deep soils, abundant water, unique habitats, and pastoral countryside.

Coalitions of regional lobby groups drive state and federal farm legislation to set high standards for environmental quality and provide incentives to teams of farmers, agricultural interest groups, conservation agencies, and industries to meet these standards in creative ways. Cropping and conservation practices are targeted at different landscape positions during key times of the year; each part of the landscape is seen as performing a valuable function based on its soils, topography, and hydrology. Algae is grown in constructed wetlands located where underground crop field drainage tile lines flow into streams to produce biodiesel and to purify agricultural waste products. Trucks and trains powered by biodiesel haul perennial biomass to ethanol plants that fuel flex-fuel hybrid vehicles. Bottomlands and sloping fields are used for rotational grazing or for growing woody crops such as hazelnuts, poplar for ethanol, or hardwood trees for veneer and lumber. Dirt trails and public access points are installed alongside stream corridors and bike trails connect small towns.

An aggressive marketing strategy, "Rurallowa. com," is developed to attract young entrepreneurs and professionals, many who work via the internet, to the Iowa countryside. Families from across the U.S. are enticed by Iowa's affordable housing and by opportunities to raise animals, garden, hunt, fish, watch wildlife, and participate in small town life. Regional programs assist young farmers, partnering them with retiring farmers, land owners, and local markets. Farmers and nonfarm rural residents recognize their interdependence and forge a set of shared values, focused on preservation of Iowa's countryside and farming lifestyle. Because of the work of community action coalitions, many rural towns become important meeting places with thriving businesses and schools.

\section{DISCUSSION}

Workshop participants agreed that the bioeconomy will shape Iowa's agricultural landscapes in ways that are currently unclear, creating new challenges and new opportunities for conservation. The trajectories and outcomes described by the previous scenarios vary markedly, yet each is a plausible interpretation of the best available scientific and stakeholder information (Fig. 3, Table 2). Comparison of scenarios illustrates that different outcomes hinge upon the type and quality of relationships among social and ecological system components, including collective decisions of multilevel social actors. These differences can be summarized in two ways: (1) multiscale, multiperspective system understanding, and (2) efficacy of regional actors to effect change.

Resilience science suggests that quantitative cause and effect models often fail to predict environmental outcomes because they do not incorporate the perspectives of social actors who intervene and alter a system's trajectory (Gunderson and Holling 2002, Peterson et al. 2004, Folke 2005). The heuristic model developed in this research (Fig. 3) advances 
understanding of how the Corn Belt socialecological system may respond to the bioeconomy by integrating knowledge from stakeholders who view this system from different scales and perspectives (Table 2). Scenarios illustrate how human actors can maintain a system in its current configuration, i.e., tweak, adapt a system's configuration to achieve desired outcomes, or transform a system into a fundamentally new configuration (for a discussion of adaptation and transformation in social-ecological systems, see Gunderson and Holling 2002, Walker et al. 2002, Walker and Salt 2006).

Current approaches to science-based management of natural resources may also fail because they optimize certain focal outcomes, while unrecognized feedback loops produce other unforeseen and undesirable outcomes (Gunderson and Holling 2002, Liu et al. 2007). Workshop participants suggested that agronomic initiatives, focused on maximizing production to sustain farm profitability, and conservation initiatives, focused on land retirement to improve water or wildlife, have produced unintended, negative outcomes. To move beyond this nearsightedness, these leaders emphasized the importance of the systems approach used in the heuristic models underlying scenarios (Fig. 3, Table 2). To illustrate different ways of responding to complexity, scenario 1 prioritizes linear understanding and optimization of a few focal system components, whereas scenarios 2 and 3 add increased understanding of feedback loops among local, regional, and macroscale drivers of change (Figs. 4a-4c).

As regional actors gain a more nuanced understanding of the system, their efficacy to affect systemic change increases. In scenario 1 , regional and local outcomes are principally driven by macroscale markets, technologies, and policies (Fig. 4a). Change seems unlikely or risky, and agricultural production is maintained at the expense of other desired system outcomes. In scenario 2, increased understanding of feedback loops enables consortiums of regional and local interests to adapt the influence of macroscale forces to achieve regional outcomes (Fig. 4b). In scenario 3, regional actors are able to leverage their pooled knowledge, resources, and initiative to transform macroscale drivers that are perceived as beyond local and regional control in other scenarios (Fig. 4c). This makes it possible to replace extant aspects of the current system with alternative components, i.e., markets, technologies, policies, partnerships, aspects of culture, land cover types, and rural economies, explicitly designed to achieve desired outcomes.

The models and scenarios arising from this study add to a growing body of research highlighting the intermediary role of regional institutions in brokering knowledge, resources, and decisions among stakeholders and across scales to maximize the vitality of communities and ecosystems (Brondizio et al. 2009). If macroscale markets, technologies, and farm policies associated with the emerging bioeconomy are allowed to be the overriding drivers of farmer decision making, Iowa's agricultural landscapes will likely become highly efficient at row crop production at the cost of other desired outcomes. However, state leaders suggest that adaptive or transformative change in response to these macroscale drivers is possible if a coordinated strategy is implemented across multiple levels of the system.

\section{CONCLUSION}

In reality, the future will not look like any one of the scenarios developed in this research, but will likely include some components of each, as well as other options hitherto unexplored. However, the visions of the future and of system understanding offered by each scenario can help to guide future decision making by revealing current challenges and leverage points for change in the Corn Belt social-ecological system. Comparing potential responses to bioenergy development in the Corn Belt with strategies being implemented in other regions will enhance the ability of both scientists and decision makers to achieve desired outcomes during this time of rapid system change.

The scenarios in this research suggest that strategic placement of perennial conservation practices in Iowa's row crop agricultural landscapes may have the potential to bolster desired multiobjective system outcomes. However, to realize potential social and ecological benefits, these practices will need to be supported by socio-cultural, economic, political, and legal drivers at national, state, and community levels. The results of adaptive change at only one level of the system are likely to be dampened by the overwhelming power of stronger exogenous variables that characterize the current system configuration. 
Regional stakeholders suggested, however, that a different system configuration is possible for the future; one that increases the social, ecological, and economic output of Iowa's agricultural landscapes through more careful use of Iowa's abundant natural and cultural resources. They suggest that such a transformation would require coordinated change across levels in the system. Our research suggests that, within the Corn Belt, state and regional leaders are positioned at a key "meso"-scale, and may be able to leverage change within both macro and micro levels of the system.

Responses to this article can be read online at: http://www.ecologyandsociety.org/voll6/iss 1/art10/ responses/

\section{Acknowledgments:}

We thank workshop participants for their honesty and insight. We also thank Tricia Knoot and Kris Atwell for comments improving earlier drafts of this manuscript and Drake Larsen for assistance with workshop organization, transcription, and analysis. This research is funded by Leopold Center for Sustainable Agriculture, USDA Sustainable Agriculture Research and Education (SARE), U.S. Forest Service Northern Research Station, and Iowa State University.

\section{LITERATURE CITED}

Alley, R. B., J. Marotzke, W. D. Nordhaus, J. T. Overpeck, D. M. Peteet, R. A. Pielke Jr, R. T. Pierrehumbert, P. B. Rhines, T. F. Stocker, L. D. Talley, and J. M. Wallace. 2003. Abrupt climate change. Science 299:2005-2010.

Atwell, R. C., L. A. Schulte, and L. M. Westphal. 2009a. Landscape, community, countryside: linking biophysical and social scales in US Corn Belt agricultural landscapes. Landscape Ecology 24:791-806.

Atwell, R. C., L. A. Schulte, and L. M. Westphal. $2009 \mathrm{~b}$. Linking resilience theory and diffusion of innovations theory to understand the potential for perennials in the U.S. Corn Belt. Ecology and Society 14 (1): 30. [online] URL: http://www.ecolo gyandsociety.org/vol14/iss1/art30/.
Atwell, R. C., L. A. Schulte, and L. M. Westphal. 2010. How to build multifunctional agricultural landscapes in the U.S. Corn Belt: add perennials and partnerships. Land Use Policy 27:1082-1090.

Ajzen, I. 2005. Attitudes, personality, and behavior. Open University Press, New York, New York, USA.

Best, L. B., K. E. Freemark, J. J. Dinsmore, and M. Camp. 1995. A review and synthesis of habitat use by breeding birds in agricultural landscapes of Iowa. American Midland Naturalist 134:1-29.

Brand, F. S., and K. Jax. 2007. Focusing the meaning(s) of resilience: resilience as a descriptive concept and a boundary object. Ecology and Society 12(1): 23. [online] URL: http://www.ecologyandso ciety.org/vol12/iss1/art23/.

Brondizio, E. S., E. Ostrom, and O. R. Young. 2009. Connectivity and the governance of multi-level social-ecological systems: the role of social capital. Annual Review of Environment and Natural Resources 34:253-278.

Broussard, W., and R. E. Turner. 2009. A century of changing land-use and water-quality relationships in the continental US. Frontiers in Ecology and the Environment 7:302-307.

Crumpton, W. G. 2001. Using wetlands for water quality improvement in agricultural watersheds: importance of a watershed scale approach. Water Science and Technology 44:559-564.

Environmental Working Group (EWG). 2006. Farm subsidy database. Washington, D.C., USA. [online] URL: http://www.ewg.org/farm/.

Field, C. B., J. E. Campbell, and D. B. Lobell. 2008. Biomass energy: the scale of the potential resource. Trends in Ecology and Evolution 23:65-72.

Fliegel, F. C., and P. F. Korsching. 2001. Diffusion research in rural sociology: the record and prospects for the future. Social Ecology Press, Middleton, Wisconsin, USA.

Folke, C. 2005. Adaptive governance of socialecological systems. Annual Review of Environment and Resources 30:441-473. 
Glover, J. D., J. P. Reganold, L. W. Bell, J. Borevitz, E. C. Brummer, E. S. Buckler, C. M. Cox, T. S. Cox, T. E. Crews, S. W. Culman, L. R. DeHaan, D. Eriksson, B. S. Gill, J. Holland, F. Hu, B. S. Hulke, A. M. H. Ibrahim, W. Jackson, S. S. Jones, S. C. Murray, A. H. Paterson, E. Ploschuk, E. J. Sacks, S. Snapp, D. Tao, D. L. Van Tassel, L. J. Wade, D. L. Wyse, and Y. Xu. 2010. Increased food and ecosystem security via perennial grains. Science 328:1638-1639.

Gunderson, L. H., and C. S. Holling. 2002. Panarchy: understanding transformations in human and natural systems. Island Press, Washington, D.C, USA.

Handwerker, W. P. 2005. Sample design. Pages 429-436 in K. Kempf-Leonard, editor. Encyclopedia of social measurement. Academic Press, Burlington, Massachusetts, USA.

Hatfield, J. L., L. D. McMullen, and C. S. Jones. 2008. Nitrate-N patterns in the Raccoon River Basin related to agricultural practices. Journal of Soil and Water Conservation 63:292-299.

Heady, E. O., E. O. Haroldsen, L. V. Mayer, and L. G. Tweeten. 1965. Roots of the farm problem: changing technology, changing capital use, changing labor needs. Iowa State University Press, Ames, Iowa, USA.

Hinkamp D., T. Borich, J. Euken, and S. Devlin. 2007. County bioeconomy discussion results. Iowa State University Extension, Ames, Iowa, USA.

Jordan N, G. Boody, W. Broussard, J. D. Glover, D. Keeney, B. H. McCown, G. McIsaac, M. Muller, H. Murray, J. Neal, C. Pansing, R. E. Turner, K. Warner, and D. Wyse. 2007. Sustainable development of the bioeconomy. Science 316:1570-1571.

Keeney, D., and L. Kemp. 2002. A new agricultural policy for the United States. Prepared for the NATO Advanced Research Workshop on Biodiversity Conservation and Rural Sustainability, November 2002. The Minnesota Project, St. Paul, Minnesota, USA. [online] URL: http://www.mnproject.org/pdf/ A $\% 20 \mathrm{New} \% 20$ Agriculture $\% 20$ Policy $\% 20$ for $\% 20$ the $\%$ 20U.S. $\% 20$ by $\% 20$ Dennis $\% 20$ Keeney $\% 20 \% 20$ Lo.. pdf.
Landis, D. A., M. M. Gardiner, W. van der Werf, and S. M. Swinton. 2008. Increasing corn for biofuel production reduces biocontrol services in agricultural landscapes. Proceedings of the National Academy of Sciences 105:20552-20557.

Liu, J., T. Dietz, S. R. Carpenter, M. Alberti, C. Folke, E. Moran, A. N. Pell, P. Deadman, T. Kratz, J. Lubchenco, E. Ostrom, Z. Ouyang, W. Provencher, C. L. Redman, S. H. Schneider, and W. W. Taylor. 2007. Complexity of coupled human and natural systems. Science 317:1513-1516.

Lobao, L., and C. W. Stofferahn. 2007. The community effects of industrialized farming: social science research and challenges to corporate farming laws. Agriculture and Human Values 25:219-240.

McCown, R. L. 2005. New thinking about farmer decision makers. In J. L. Hatfield, editor. The farmer's decision. Soil and Water Conservation Society, Ankeny, Iowa, USA.

Miles, M. B., and A. M. Huberman. 1994. Qualitative data analysis: an expanded sourcebook. Second edition. Sage Publications, Thousand Oaks, California, USA.

Millar, C. I., N. L. Stephenson, and S. L. Stephens. 2007. Climate change and forests of the future: managing in the face of uncertainty. Ecological Applications 17:2145-2151.

Monchuk, D. C., J. A. Miranowski, D. J. Hayes, and B. A. Babcock. 2007. Analysis of regional economic growth in the U.S. Midwest. Review of Agricultural Economics 29:17-39.

Morton, L. W. 2008. The role of civic structure in achieving performance based watershed management. Society and Natural Resources 21:751-766.

Nassauer, J. I., M. V. Santelmann, and D. Scavia. 2007. From the Corn Belt to the gulf: societal and environmental implications of alternative agriculture futures. Resources for the Future Press, Washington, D.C., USA.

Peterson, G. D., T. D. Beard Jr, B. E. Beisner, E. M. Bennett, S. R. Carpenter, G. S. Cumming, C. L. Dent, and T. D. Havlicek. 2003. Assessing future ecosystem services: a case study of the Northern 
Highlands Lake District, Wisconsin. Ecology and Society 7(3): 1. [online] URL: http://www.consecol. org/vol7/iss3/art1.

Peterson, G. D., G. S. Cumming, and S. R. Carpenter. 2004. Scenario planning: a tool for conservation in an uncertain world. Conservation Biology 12:358-366.

Porter, J., R. Costanza, H. Sandhu, L. Sigsgaard, and S. Wratten. 2009. The value of producing food, energy, and ecosystem services within an agroecosystem. Ambio 38:186-193.

QSR. 2006. NVivo7 (qualitative data management and analysis software). QSR International, Doncaster, Australia.

Ragauskas, A. J., C. K. Williams, B. H. Davison, G. Britovsek, J. Cairney, C. A. Eckert Jr., W. J. Frederick Jr., J. P. Hallett, D. J. Leak, C. L. Liotta, J. R. Mielenz, R. Murphy, R. Templer, and T. Tschaplinski. 2006. The path forward for biofuels and biomaterials. Science 311:484-489.

Robertson, G. P., V. H. Dale, O. C. Doering, S. P. Hamburg, J. M. Melillo, M. M. Wander, W. J. Parton, P. R. Adler, J. N. Barney, R. M. Cruse, C. S. Duke, P. M. Fearnside, R. F. Follett, H. K. Gibbs, J. Goldemberg, D. J. Mladenoff, D. Ojima, M. W. Palmer, A. Sharpley, L. Wallace, K. C. Weathers, J. A. Wiens, and W. W. Wilhelm. 2008. Sustainable biofuels redux. Science 322:49-50.

Santelmann, M. V., D. White, K. Freemark, J. I. Nassauer, J. M. Eilers, K. B. Vache, B. J. Danielson, R. C. Corry, M. E. Clark, S. Polasky, R. M. Cruse, J. Sifneos, H. Rustigian, C. Coiner, J. Wu, and D. Debinski. 2004. Assessing alternative futures for agriculture in Iowa, USA. Landscape Ecology 19:357-374.

Schulte, L. A., H. Asbjornsen, R. Atwell, C. Hart, M. Helmers, T. Isenhart, R. Kolka, M. Liebman, J. Neal, M. O'Neal, S. Secchi, R. Schultz, J. Thompson, and J. Tyndall. 2008. A targeted conservation approach for improving environmental quality: multiple benefits and expanded opportunities. Iowa State University Extension, Ames, Iowa, USA.

Schulte, L. A., M. Liebman, H. Asbjornsen, and T. R. Crow. 2006. Agroecosystem restoration through strategic integration of perennials. Journal of Soil and Water Conservation 61:164A-169A.
Schultz, R. C., T. M. Isenhart, W. W. Simpkins, and J. P. Colletti. 2004. Riparian forest buffers in agroecosystems: lessons learned from the Bear Creek Watershed, central Iowa, USA. Agroforestry Systems 61:35-50.

Secchi, S., J. Tyndall, L. A. Schulte, and H. Asbjornsen. 2008. Raising the stakes: high crop prices and conservation. Journal of Soil and Water Conservation 63:68A-74A.

Stein, T. V., D. H. Anderson, and T. Kelly. 1999. Using stakeholders' values to apply ecosystem management in an upper midwest landscape. Environmental Management 24:399-413.

Tilman, D., J. Hill, and C. Lehman. 2006. Carbonnegative biofuels from low-input high-diversity grassland biomass. Science 314:1598-1600.

United States Department of Agriculture National Agricultural Statistics Service (USDA NASS). 2004. 2002 census of agriculture. U.S. Department of Agriculture, Washington, D.C., USA. [online] URL: http://www.agcensus.usda.gov/Publications/2002/ USVolume104.pdf.

United States Environmental Protection Agency (US EPA). 2007. Hypoxia in the northern Gulf of Mexico: an update by the EPA science advisory board. EPA Science Advisory Board Report EPASAB-08-003, U.S. Environmental Protection Agency, Washington, D.C., USA. [online] URL: http://yosemite.epa.gov/sab/sabproduct.nsf/0/ C3D2F27094E03F90852573B800601D93/\$File/EPASAB-08-003complete.unsigned.pdf.

Vitousek, P. M., R. Naylor, T. Crews, M. B. David, L. E. Drinkwater, E. Holland, P. J. Johnes, J. Katzenberger, L. A. Martinelli, P. A. Matson, G. Nziguheba, D. Ojima, C. A. Palm, G. P. Robertson, P. A. Sanchez, A. R. Townsend, and F. S. Zhang. 2009. Nutrient imbalances in agricultural development. Science 324:1519-1520.

Walker, B., S. Carpenter, J. Anderies, N. Abel, G. S. Cumming, M. Janssen, L. Lebel, J. Norberg, G. D. Peterson, and R. Pritchard. 2002. Resilience management in social-ecological systems: a working hypothesis for a participatory approach. Conservation Ecology 6(1): 14. [online] URL: http ://www.ecologyandsociety.org/vol6/iss1/art14/.

Walker, B., and D. Salt. 2006. Resilience thinking: sustaining people and ecosystems in a changing world. Island Press, Washington, D.C., USA. 